\title{
REAKCJA ROŚLIN SOI NA SZCZEPIENIE NASION NITRAGINĄ ORAZ NAWOŻENIE STARTOWE AZOTEM*
}

\author{
REACTION OF SOYBEAN PLANTS TO THE VACCINATION OF SEEDS \\ WITH NITRAGINE AND INITIAL NITROGEN FERTILIZATION
}

\begin{abstract}
Streszczenie. Ścisłe doświadczenie polowe wykonano w Stacji Doświadczalnej Oceny Odmian w Przecławiu w latach 2011-2013. Celem badań było określenie reakcji roślin soi na szczepionkę bakteryjną - nitraginę oraz nawożenie startowe azotem. Czynnikiem doświadczenia był sposób zaopatrzenia roślin w azot na czterech poziomach: nitragina, dawka startowa azotu $\left(25 \mathrm{~kg} \cdot \mathrm{ha}^{-1}\right)$, nitragina $\mathrm{z}$ dawką startową azotu $\left(25 \mathrm{~kg} \cdot \mathrm{ha}^{-1}\right)$ oraz obiekt kontrolny. Warunki pogodowe wywarly znaczący wpływ na przebieg wegetacji roślin oraz plon nasion. Sposób zaopatrzenia roślin w azot wpłynął na wydłużenie poszczególnych faz rozwojowych w porównaniu z kontrolą oraz zróżnicował cechy biometryczne roślin. Na obiektach nawożonych dawką startową azotu odnotowano większe wyleganie roślin niż na obiektach z nitraginą oraz kontrolnym. Sposób zaopatrzenia roślin w azot istotnie zróżnicował wskaźniki SPAD oraz LAI, natomiast nie modyfikował wskaźnika MTA. Nawożenie startowe azotem wpłynęło na wzrost liczby nasion w strąku w porównaniu z kontrolą oraz wzrost MTN w stosunku do obiektu z nitraginą i kontrolnego. Szczepienie nasion siewnych nitraginą istotnie zwiększyło liczbę brodawek korzeniowych. Średnio na korzeniach roślin soi wykształciło się 16 brodawek. Plon nasion był w głównej mierze uzależniony od lat badań. Sposób zaopatrzenia roślin w azot istotnie zwiększył plonowanie soi w porównaniu z kontrolą. Potwierdzono również, że nawożenie startowe azotem wpłynęło istotnie na wzrost plonu nasion w porównaniu ze stosowaną szczepionką bakteryjną - nitraginą.
\end{abstract}

Słowa kluczowe: soja, szczepionka bakteryjna - nitragina, nawożenie startowe azotem, plon nasion, SPAD, LAI, MTA

*Badania prowadzono $\mathrm{w}$ ramach projektu badawczego Narodowego Centrum Nauki nr $\mathrm{N}$ N310 003040 . 
Jarecki, W., Bobrecka-Jamro, D. (2016). Reakcja roślin soi na szczepienie nasion nitraginą oraz nawożenie startowe azotem. Nauka Przyr. Technol., 10, 1, \#12. DOI: 10.17306/J.NPT.2016.1.12

\section{Wstęp}

Soja należy do ważnych gospodarczo roślin uprawnych na świecie. W Polsce areał uprawy soi jest jednak nieduży, co wynika głównie z uwarunkowań siedliskowych oraz importu na rynek europejski śruty sojowej do produkcji pasz (Florek i in., 2012; Jerzak i in., 2012). Dobek i Dobek (2008) oraz Dobek i in. (2009) uważają, że możliwy jest wzrost produkcji soi w Polsce, na co wskazują wykonane obliczenia efektywności ekonomicznej uprawy soi w krajowych gospodarstwach rolnych.

Konieczne jest jednak upowszechnianie nowych odmian soi, które w krajowych warunkach plonowałyby obficie i stabilnie w latach oraz charakteryzowały się bardzo dobrą wartością użytkową. Nie mniej ważna jest poprawna agrotechnika. Bury i Nawracała (2004) uważają, że szczególnie ważnym zabiegiem w uprawie soi jest szczepienie nasion siewnych nitraginą, bakterie brodawkowe Bradyrhizobium japonicum nie występują bowiem w polskich glebach, z wyjątkiem pól, na których w zmianowaniu uprawia się soję.

Rośliny soi, dzięki symbiozie z bakteriami brodawkowymi wiążącymi wolny azot atmosferyczny, wykorzystują azot z powietrza, i w efekcie tego wystarcza im zmniejszone nawożenie azotowe (Lorenc-Kozik i Pisulewska, 2003; Martyniuk, 2012). Ma to duże znaczenie gospodarcze, środowiskowe i ekonomiczne (Podleśny, 2005). Przy obfitym brodawkowaniu symbiotyczne bakterie azotowe mogą dostarczyć roślinom soi nawet $100 \mathrm{~kg} \mathrm{~N}$ na 1 ha (Filoda i Mrówczyński, red., 2012).

Celem badań było określenie reakcji roślin soi (odmiana 'Aldana') na dawkę startową azotu i szczepionkę bakteryjną (nitragina). W hipotezie badawczej założono, że zastosowane źródła azotu - symbiotycznego i/lub nawozowego - wpłynęły różnicująco na badane parametry roślin soi oraz wielkość plonu nasion.

\section{Material i metody}

Ścisłe doświadczenie polowe wykonano w latach 2011-2013 w Stacji Doświadczalnej Oceny Odmian w Przecławiu (50 $\left.11^{\prime} \mathrm{N}, 21^{\circ} 29^{\prime} \mathrm{E}\right)$.

Czynnikiem doświadczenia był sposób zaopatrzenia roślin w azot: nitragina, dawka startowa azotu $\left(25 \mathrm{~kg} \cdot \mathrm{ha}^{-1}\right)$, nitragina $\mathrm{z}$ dawką startową azotu $\left(25 \mathrm{~kg} \cdot \mathrm{ha}^{-1}\right)$ oraz obiekt kontrolny. Doświadczenia zakładano w czterech powtórzeniach w układzie losowanych bloków.

Doświadczenie założono na glebie średniej, kompleksu pszennego bardzo dobrego. Gleba wykazywały odczyn lekko kwaśny. Zasobność w przyswajalny fosfor i potas była średnia, a w przyswajalny magnez - duża. Zawartość azotu mineralnego w glebie (z poziomu $0-60 \mathrm{~cm}$ ) była corocznie mała.

Nasiona do siewu pochodziły z firmy Hodowla Roślin Strzelce Sp. z o.o. Grupa IHAR. Przed wysiewem nasiona zaprawiono zaprawą Sarfun T 450 FS (250 ml na 100 $\mathrm{kg}$ nasion). Szczepionka bakteryjna (nitragina) pochodziła z firmy Biofood Wałcz. Do nawożenia startowego azotem użyto saletry amonowej 34-procentowy.

Powierzchnia poletek wynosiła 19,5 $\mathrm{m}^{2}$ (do zbioru 16,5 $\mathrm{m}^{2}$ ). Przedplonem corocznie była forma ozima pszenicy zwyczajnej. Zabiegi agrotechniczne wykonano według za- 
Jarecki, W., Bobrecka-Jamro, D. (2016). Reakcja roślin soi na szczepienie nasion nitraginą oraz nawożenie startowe azotem. Nauka Przyr. Technol., 10, 1, \#12. DOI: 10.17306/J.NPT.2016.1.12

sad przyjętych w uprawie soi oraz zgodnie z metodyką COBORU. Wysiano 90 nasion na $1 \mathrm{~m}^{2}$, rozstawa rzędów wyniosła $21,4 \mathrm{~cm}$, a głębokość siewu $-3-4 \mathrm{~cm}$. Siewu dokonano w dniach: 5.05.2011 roku, 4.05.2012 roku oraz 7.05.2013 roku. Nawożenie fosforowo-potasowe zastosowano jesienią $\mathrm{w}$ formie superfosfatu potrójnego granulowanego i soli potasowej. Dawki nawozów wyniosły: $70 \mathrm{~kg} \mathrm{P}_{2} \mathrm{O}_{5}$ na 1 ha i $120 \mathrm{~kg} \mathrm{~K}_{2} \mathrm{O}$ na 1 ha. Herbicydów nie stosowano, a zachwaszczenie wtórne usunięto ręcznie.

W trakcie prowadzenia doświadczeń odnotowano następujące fazy rozwojowe roślin: wschody, pąkowanie, kwitnienie, dojrzałość pełna. W fazie początku kwitnienia policzono brodawki korzeniowe na 10 roślinach losowo pobranych $\mathrm{z}$ każdego poletka.

$\mathrm{W}$ okresie pełni wschodów i przed zbiorem obliczono obsadę roślin na $1 \mathrm{~m}^{2}$. W fazie dojrzałości technicznej z każdego poletka wybrano 20 roślin do pomiarów biometrycznych i określenia elementów struktury plonu.

Architekturę łanu zmierzono indeksem LAI (ang. Leaf Area Index) oraz wskaźnikiem MTA (ang. Mean Tip Angle) za pomocą aparatu LI-COR, wskaźnik zieloności zaś oceniono miernikiem SPAD 502P (Konica Minolta). Pomiarów LAI i MTA dokonano dwukrotnie: w fazie końca pąkowania i w fazie pierwszego płaskiego strąka. Z kolei wskaźnik SPAD zmierzono trzykrotnie: w fazie dwóch liści, w fazie końca pąkowania oraz $\mathrm{w}$ fazie pierwszego płaskiego strąka.

Plon nasion przeliczono na 1 ha po uwzględnieniu 15-procentowej wilgotności. Uzyskany plon skorygowano o brakujące rośliny pobrane przed zbiorem do pomiarów biometrycznych.

Istotność różnic pomiędzy wartościami cech stwierdzono na podstawie półprzedziałów ufności Tukeya, przy poziomie istotności $\alpha=0,05$. Obliczenia wykonano programem statystycznym FR-ANALWAR-5FR autorstwa prof. Rudnickiego.

Warunki pogodowe zestawiono z danych Stacji Doświadczalnej Oceny Odmian w Przecławiu. Analizę próbek glebowych wykonano w Okręgowej Stacji Chemiczno-Rolniczej w Rzeszowie.

\section{Wyniki i dyskusja}

Warunki pogodowe były zmienne w latach badań i wywarły znaczący wpływ na przebieg wegetacji oraz plonowanie soi. Intensywne opady odnotowano w lipcu 2011 roku oraz w maju i czerwcu 2013 roku. Średnie miesięczne temperatury były mniej zróżnicowane w latach. W trakcie prowadzenia badań najcieplejszymi miesiącami były: sierpień w 2011 roku oraz lipiec w 2012 i 2013 roku (tab. 1).

Przebieg wegetacji roślin soi był uzależniony od warunków pogodowych w latach badań. Wschody roślin ukazały się najwcześniej w 2013 roku, a najpóźniej - w 2011 roku. Okres wegetacji trwał średnio od 120 dni w 2011 roku do 130 dni w 2013 roku. Sposób zaopatrzenia roślin w azot wpłynął na opóźnienie wchodzenia roślin w poszczególne fazy rozwojowe. Zastosowanie azotu mineralnego oraz azotu mineralnego łącznie z nitraginą wydłużyło okres wegetacji roślin soi w porównaniu z kontrolą (tab. 2).

W doświadczeniach Burego i Nawracały (2004) wzrost i rozwój roślin soi, a zwłaszcza długość okresu wegetacji, zależały głównie od warunków meteorologicznych.

Zastosowanie dawki startowej azotu, a także dawki startowej azotu łącznie z nitraginą wpłynęło na zwiększenie wysokości roślin soi w porównaniu z obiektem kontrolnym. 
Jarecki, W., Bobrecka-Jamro, D. (2016). Reakcja roślin soi na szczepienie nasion nitraginą oraz nawożenie startowe azotem. Nauka Przyr. Technol., 10, 1, \#12. DOI: 10.17306/J.NPT.2016.1.12

Tabela 1. Warunki pogodowe w latach 2011-2013

Table 1. Weather conditions in 2011-2013

\begin{tabular}{|l|r|c|c|c|r|r|}
\hline \multirow{2}{*}{$\begin{array}{c}\text { Miesiąc } \\
\text { Month }\end{array}$} & \multicolumn{3}{|c|}{$\begin{array}{c}\text { Suma opadów } \\
\text { Sum of rainfall } \\
(\mathrm{mm})\end{array}$} & \multicolumn{3}{c|}{$\begin{array}{c}\text { Średnia temperatura powietrza } \\
\text { Average air temperature } \\
\left({ }^{\circ} \mathrm{C}\right)\end{array}$} \\
\cline { 2 - 7 } & 2011 & 2012 & 2013 & 2011 & 2012 & 2013 \\
\hline Kwiecień - April & 52,3 & 21,7 & 40,4 & 10,00 & 9,89 & 8,84 \\
Maj - May & 38,1 & 66,7 & 111,7 & 13,80 & 14,72 & 15,00 \\
Czerwiec - June & 78,6 & 66,9 & 192,4 & 18,10 & 18,24 & 18,52 \\
Lipiec - July & 291,8 & 65,6 & 58,3 & 18,50 & 20,87 & 19,36 \\
Sierpień - August & 58,6 & 61,8 & 21,2 & 19,10 & 18,75 & 18,59 \\
\hline
\end{tabular}

Tabela 2. Przebieg wegetacji soi od daty siewu (dni)

Table 2. Course of soybean vegetation from date of sowing (days)

\begin{tabular}{|l|l|c|c|c|c|}
\hline $\begin{array}{c}\text { Termin siewu } \\
\text { Sowing date }\end{array}$ & $\begin{array}{c}\text { Sposób zaopa- } \\
\text { trzenia roślin } \\
\text { w azot } \\
\text { Method of plant } \\
\text { nitrogen supply }\end{array}$ & $\begin{array}{c}\text { Wschody } \\
\text { (początek) } \\
\text { Emergence } \\
\text { (beginning) }\end{array}$ & $\begin{array}{c}\text { Pąkowanie } \\
\text { (początek) } \\
\text { Budding } \\
\text { (beginning) }\end{array}$ & $\begin{array}{c}\text { Kwitnienie } \\
\text { (pełnia) } \\
\text { Flowering } \\
\text { (climax) }\end{array}$ & $\begin{array}{c}\text { Dojrzałość pełna } \\
\text { Full ripeness }\end{array}$ \\
\hline 5.05 .2011 & A & 26 & 42 & 57 & 117 \\
& B & 26 & 43 & 58 & 119 \\
& C & 26 & 43 & 58 & 122 \\
& D & 26 & 43 & 58 & 121 \\
\cline { 2 - 6 } & Średnio-Mean & 26,0 & 42,8 & 57,8 & 119,8 \\
\hline \multirow{2}{*}{4.05 .2012} & A & 13 & 46 & 65 & 122 \\
& B & 14 & 47 & 66 & 124 \\
& C & 14 & 47 & 66 & 126 \\
& D & 14 & 47 & 67 & 126 \\
\cline { 2 - 6 } & Średnio - Mean & 13,8 & 46,8 & 66,0 & 124,5 \\
\hline 7.05 .2013 & A & 9 & 41 & 72 & 129 \\
& B & 9 & 42 & 73 & 130 \\
& C & 9 & 42 & 73 & 131 \\
& D & 9 & 42 & 73 & 131 \\
\cline { 2 - 6 } & Średnio - Mean & 9,0 & 41,8 & 72,8 & 130,3 \\
\hline Średnia z lat & A & 16,0 & 43,0 & 64,7 & 122,7 \\
Mean in years & B & 16,3 & 44,0 & 65,7 & 124,3 \\
& C & 16,3 & 44,0 & 65,7 & 126,3 \\
& D & 16,3 & 44,0 & 66,0 & 126,0 \\
\hline
\end{tabular}

A - kontrola, B - nitragina, C - dawka startowa azotu, D - nitragina z dawką startową azotu.

$\mathrm{A}$ - control, B - nitragine, $\mathrm{C}$ - initial dose of nitrogen, D - nitragine with initial dose of nitrogen. 
Jarecki, W., Bobrecka-Jamro, D. (2016). Reakcja roślin soi na szczepienie nasion nitraginą oraz nawożenie startowe azotem. Nauka Przyr. Technol., 10, 1, \#12. DOI: 10.17306/J.NPT.2016.1.12

Istotna różnica omawianej cechy wystąpiła również pomiędzy roślinami nawożonymi startowo azotem a roślinami po zastosowaniu nitraginy. Średnia wysokość roślin soi wyniosła 79,63 cm. W doświadczeniu Burego i Nawracały (2004) średnia wysokość roślin soi wyniosła 49,2 cm, a u Bujaka i Franta (2009) - od 42,1 do 85,9 cm, w zależności od odmiany.

Na wyższe osadzenie pierwszego strąka korzystnie wpłynęły badane sposoby zaopatrzenia roślin w azot, przy czym istotną różnicę w odniesieniu do kontroli udowodniono tylko po łącznym zastosowaniu nitraginy z nawożeniem azotowym. Średnio rośliny soi osadziły pierwszy strąk na wysokości $14,1 \mathrm{~cm}$. Bujak i Frant (2009) podają, że rośliny soi odmiany 'Aldana' zawiązują pierwsze strąki na wysokości około $10 \mathrm{~cm}$. W doświadczeniu Burego i Nawracały (2004) prowadzonym na kilku odmianach soi najniższy strąk był osadzony średnio na wysokości $10,3 \mathrm{~cm}$.

Wykonane badania wykazały, że wyleganie roślin wzrastało po zastosowaniu dawki startowej azotu oraz dawki startowej azotu łącznie z nitraginą. Istotnie mniejsze nasilenie wylegania odnotowano na obiekcie z nitraginą oraz kontrolnym (tab. 3). W doświadczeniu Lorenc-Kozik i Pisulewskiej (2003) nasilone wyleganie roślin wynikało ze zbyt dużej sumy opadów w lipcu i nadmiernego uwilgotnienia gleby.

Tabela 3. Obsada roślin i wybrane pomiary morfologiczne roślin (średnia z lat)

Table 3. Plant density and selected morphological measurements of plants (mean in years)

\begin{tabular}{|c|c|c|c|c|c|}
\hline \multirow{2}{*}{$\begin{array}{l}\text { Sposób zaopatrze- } \\
\text { nia roślin w azot } \\
\text { Method of plant } \\
\text { nitrogen supply }\end{array}$} & \multicolumn{2}{|c|}{$\begin{array}{l}\text { Obsada roślin na } 1 \mathrm{~m}^{2} \\
\text { Plant number per } 1 \mathrm{~m}^{2}\end{array}$} & \multirow{2}{*}{$\begin{array}{c}\text { Wysokośś roślin } \\
\text { Plant height } \\
\text { (cm) }\end{array}$} & \multirow{2}{*}{\begin{tabular}{|c|} 
Wysokość \\
osadzenia pierw- \\
szego strąka \\
Height of the \\
first pod \\
(cm)
\end{tabular}} & \multirow{2}{*}{$\begin{array}{c}\text { Wyleganie } \\
\text { Lodging } \\
1-9^{\circ}\end{array}$} \\
\hline & $\begin{array}{c}\text { po wschodach } \\
\text { after emergence }\end{array}$ & $\begin{array}{l}\text { przed zbiorem } \\
\text { before harvest }\end{array}$ & & & \\
\hline A & 81,62 & 75,83 & 70,28 & 13,20 & 8,42 \\
\hline B & 88,46 & 79,13 & 77,43 & 13,65 & 8,17 \\
\hline $\mathrm{C}$ & 84,75 & 77,92 & 86,46 & 14,59 & 7,42 \\
\hline $\mathrm{D}$ & 85,13 & 78,17 & 84,34 & 14,79 & 7,33 \\
\hline Średnio - Mean & 84,99 & 77,76 & 79,63 & 14,06 & 7,84 \\
\hline $\mathrm{NIR}_{0,05}-\mathrm{LSD}_{0.05}$ & r.n. - n.s. & r.n. - n.s. & 8,592 & 1,580 & 0,634 \\
\hline
\end{tabular}

Objaśnienie A, B, C, D - jak w tabeli 2, r.n. - różnica nieistotna.

Explanation of A, B, C, D - as in Table 2, n.s. - difference not significant.

Nawożenie azotem oraz łączne zastosowanie nitraginy z dawką azotu istotnie zwiększyło, w porównaniu z obiektem kontrolnym, wartość wskaźnika SPAD zmierzonego w fazie dwóch liści właściwych oraz w fazie końca pąkowania roślin (tab. 4). Udowodniono także, że we wszystkich badanych fazach rozwojowych dawka startowa azotu istotnie zwiększała stan odżywienia roślin w porównaniu ze szczepionką bakteryjną - nitraginą. Pomiar wskaźnika SPAD wykonany w fazie pierwszego płaskiego strąka wykazał, że dawka startowa azotu była najkorzystniejsza i istotnie zwiększyła zieloność liści w porównaniu z obiektem kontrolnym (tab. 4). Krivosudska i Filova 
Jarecki, W., Bobrecka-Jamro, D. (2016). Reakcja roślin soi na szczepienie nasion nitraginą oraz nawożenie startowe azotem. Nauka Przyr. Technol., 10, 1, \#12. DOI: 10.17306/J.NPT.2016.1.12

Tabela 4. Wartość wskaźnika SPAD (średnia z lat)

Table 4. Value of SPAD indicator (mean in years)

\begin{tabular}{|c|c|c|c|}
\hline \multirow{2}{*}{$\begin{array}{c}\text { Sposób zaopatrzenia } \\
\text { roślin w azot } \\
\text { Method of plant } \\
\text { nitrogen supply }\end{array}$} & \multicolumn{3}{|c|}{ Faza rozwojowa roślin - Phase of plant development } \\
\hline & $\begin{array}{l}\text { BBCH } 11 \\
\text { dwa liście } \\
\text { two leaves }\end{array}$ & $\begin{array}{c}\text { BBCH } 59 \\
\text { koniec pakowania } \\
\text { end of budding }\end{array}$ & $\begin{array}{c}\text { BBCH } 70 \\
\text { pierwszy płaski strąk } \\
\text { stage of flat pod }\end{array}$ \\
\hline A & 33,76 & 36,33 & 44,78 \\
\hline B & 35,76 & 36,90 & 45,02 \\
\hline $\mathrm{C}$ & 38,36 & 39,15 & 47,69 \\
\hline D & 38,43 & 38,20 & 46,23 \\
\hline Średnio - Mean & 36,58 & 37,64 & 45,68 \\
\hline $\mathrm{NIR}_{0,05}-\mathrm{LSD}_{0.05}$ & 2,036 & 1,658 & 2,491 \\
\hline
\end{tabular}

Objaśnienie A, B, C, D - jak w tabeli 2.

Explanation of A, B, C, D - as in Table 2 .

(2013) uzasadniły przydatność odczytów SPAD do porównywania genotypów soi oraz ich reakcji na stres wodny. Reddy i in. (2000) zbadali wpływ glifosatu na odczyty wskaźnika SPAD. Pozwoliło to na udowodnienie odmiennej reakcji poszczególnych odmian na zastosowaną w doświadczeniu substancję aktywną herbicydu.

Pomiar LAI wykonany w fazie końca pąkowania oraz $\mathrm{w}$ fazie pierwszego płaskiego strąka wykazał, że wszystkie badane sposoby zaopatrzenia roślin w azot istotnie zwiększyły wartość indeksu LAI w porównaniu z roślinami kontrolnymi. Wskaźnik MTA zmierzony zarówno w fazie końca pąkowania, jak i w fazie pierwszego płaskiego strąka nie był zróżnicowany czynnikiem doświadczenia (tab. 5).

Tabela 5. Wartość wskaźników LAI i MTA (średnia z lat)

Table 5. Value of LAI and MTA indicators (mean in years)

\begin{tabular}{|l|c|c|c|c|}
\hline \multirow{2}{*}{$\begin{array}{c}\text { Sposób zaopatrzenia } \\
\text { roślin w azot } \\
\begin{array}{c}\text { Method of plant } \\
\text { nitrogen supply }\end{array}\end{array}$} & $\begin{array}{c}\text { koniec pakowania } \\
\text { end of budding }\end{array}$ & $\begin{array}{c}\text { pierwszy płaski } \\
\text { strąk } \\
\text { stage of flat pod }\end{array}$ & $\begin{array}{c}\text { koniec pąkowania } \\
\text { end of budding }\end{array}$ & $\begin{array}{c}\text { pierwszy płaski } \\
\text { strakk } \\
\text { stage of flat pod }\end{array}$ \\
\hline A & 5,19 & 4,38 & 31,54 & 38,96 \\
B & 5,53 & 4,87 & 34,92 & 39,04 \\
C & 5,66 & 5,07 & 32,58 & 36,29 \\
D & 5,77 & 4,97 & 33,54 & 37,67 \\
\hline Średnio- Mean & 5,54 & 4,82 & 33,15 & 37,99 \\
\hline $\mathrm{NIR}_{0,05}-\mathrm{LSD}_{0.05}$ & 0,339 & 0,318 & r.n. - n.s. & r.n. - n.s. \\
\hline
\end{tabular}

Objaśnienie A, B, C, D - jak w tabeli 2, r.n. - różnica nieistotna.

Explanation of A, B, C, D - as in Table 2, n.s. - difference not significant. 
Jarecki, W., Bobrecka-Jamro, D. (2016). Reakcja roślin soi na szczepienie nasion nitraginą oraz nawożenie startowe azotem. Nauka Przyr. Technol., 10, 1, \#12. DOI: 10.17306/J.NPT.2016.1.12

Sposób zaopatrzenia roślin w azot korzystnie wpłynął na liczbę wykształconych strąków na roślinie w odniesieniu do kontroli (tab. 6). Uzyskane różnice nie zostały jednak udowodnione statystycznie. Lorenc-Kozik i Pisulewska (2003) podają, że plon soi jest kształtowany głównie przez liczbę strąków wytworzonych na roślinie oraz przez masę nasion z rośliny. Wymienione komponenty plonowania w doświadczeniu wspomnianych autorek wykazywały silną reakcję na nawożenie azotem. Bujak i in. (2004) podają, że przy dużej liczbie strąków na roślinie zmniejsza się w nich liczba nasion do około dwóch.

W badaniach własnych zastosowanie dawki startowej azotu spowodowało zwiększenie liczby nasion w strąku średnio o 0,49 nasiona w porównaniu z kontrolą (tab. 6).

Tabela 6. Składowe plonu oraz liczba brodawek korzeniowych na roślinie (średnia z lat) Table 6. Yield components and number of root nodules per plant (mean in years)

\begin{tabular}{|l|c|c|c|c|}
\hline $\begin{array}{c}\text { Sposób zaopatrzenia } \\
\text { roślin w azot } \\
\begin{array}{c}\text { Method of plant } \\
\text { nitrogen supply }\end{array}\end{array}$ & $\begin{array}{c}\text { Liczba straków } \\
\text { na roślinie } \\
\text { Number of pods } \\
\text { per plant }\end{array}$ & $\begin{array}{c}\text { Liczba nasion } \\
\text { w strąku } \\
\text { Number of seeds } \\
\text { per pod }\end{array}$ & $\begin{array}{c}\text { MTN } \\
\text { Mass of 1000 } \\
\text { grains } \\
(\mathrm{g})\end{array}$ & $\begin{array}{c}\text { Liczba brodawek } \\
\text { korzeniowych } \\
\text { na roślinie } \\
\text { Number of root } \\
\text { nodules per plant }\end{array}$ \\
\hline $\mathrm{A}$ & 10,88 & 2,27 & 162,8 & 14,3 \\
$\mathrm{~B}$ & 11,16 & 2,56 & 162,3 & 17,3 \\
$\mathrm{C}$ & 12,23 & 2,76 & 172,8 & 15,1 \\
$\mathrm{D}$ & 11,21 & 2,67 & 169,3 & 17,3 \\
\hline Średnio $-\mathrm{Mean}$ & 11,37 & 2,56 & 166,8 & 16,0 \\
\hline $\mathrm{NIR}_{0,05}-\mathrm{LSD}_{0.05}$ & r.n. - n.s. & 0,399 & 9,11 & 1,96 \\
\hline
\end{tabular}

Objaśnienie A, B, C, D - jak w tabeli 2, r.n. - różnica nieistotna.

Explanation of A, B, C, D - as in Table 2, n.s. - difference not significant.

Najmniejsze, a zarazem podobne wartości MTN uzyskano po użyciu nitraginy oraz na obiekcie kontrolnym (tab. 6). Istotnie większą dorodność nasion odnotowano po nawożeniu startowym azotem. W wykonanym doświadczeniu wartość MTN wyniosła średnio 166,8 g. Filoda i Mrówczyński (red., 2012) stwierdzają, że wartość MTN soi odmiany 'Aldana' jest stosunkowo duża i wynosi powyżej $170 \mathrm{~g}$. Znacznie mniejszą wartość MTN dla innych odmian soi podają Bury i Nawracała (2004). W doświadczeniu Lorenc-Kozik i Pisulewskiej (2003) nawożenie azotowe nie zróżnicowało MTN, ale zwiększyło istotnie masę nasion z rośliny. Największa z zastosowanych przez wymienionych autorów dawek (60 kg N na 1 ha) najbardziej, bo o 16\% zwiększała masę nasion z rośliny w stosunku do obiektów nie nawożonych azotem. Boros (2003) podaje, że gdy celem selekcji roślin strączkowych jest zwiększenie plonowania, to zarówno liczba strąków, jak i liczba nasion z rośliny oraz wartość MTN muszą być uwzględniane jednocześnie, szczególnie u soi.

Zgodnie z oczekiwaniami na obiektach, na których użyto szczepionki bakteryjnej, istotnie wzrosła liczba brodawek korzeniowych w porównaniu z obiektami bez szcze- 
Jarecki, W., Bobrecka-Jamro, D. (2016). Reakcja roślin soi na szczepienie nasion nitraginą oraz nawożenie startowe azotem. Nauka Przyr. Technol., 10, 1, \#12. DOI: 10.17306/J.NPT.2016.1.12

pionki (tab. 6). Należy zauważyć, że brodawkowanie wystąpiło także na obiekcie z dawką startową azotu oraz na obiekcie kontrolnym. Świadczy to o występowaniu w glebie bakterii symbiotycznych, co wynika z uprawy soi na polach doświadczalnych. Średnio na korzeniu pojedynczej rośliny soi było 16 brodawek. Korsak-Adamowicz i in. (2007) uzyskali znacznie mniej brodawek na korzeniach soi. W doświadczeniu Burego i Nawracały (2004) niski poziom plonów był spowodowany brakiem brodawkowania oraz niedoborem opadów w latach badań. Wymienieni autorzy podają, że pomimo zaprawiania nasion siewnych szczepionką bakteryjną rośliny soi słabo nawiązały symbiozę, a ich rozwój był uzależniony w dużym stopniu od zasobności gleby w azot i nawożenia mineralnego tym składnikiem. Martyniuk (2012) zwraca uwagę na konieczność doboru odpowiedniej zaprawy nasiennej, jeśli planuje się szczepienie nasion siewnych roślin strączkowych nitraginą. Księżak (2006) dodaje, że zawiązywanie brodawek korzeniowych zależy od pH gleby. Z kolei Korsak-Adamowicz i in. (2007) podają, że symbiozie bakterii brodawkowych z rośliną uprawną nie sprzyjają susza i wysoka temperatura. Willems (2006) oraz Albareda i in. (2009) konkludują, że taksonomia bakterii z rodzaju Rhizobium występujących na korzeniach roślin strączkowych zmieniła się znacznie w ciągu ostatnich lat. Nowe badania z tego zakresu są na świecie bardzo zaawansowane i nadal ewoluują (Appunu i in., 2008; Cheng, 2008; Rodríguez-Navarro i in., 2003; Sujkowska, 2009; Yang i in., 2001). Hungría i in. (2006) podkreślają ekonomiczne i ekologiczne korzyści wynikające z zastąpienia nawozów azotowych szczepieniem nasion soi, nawet na glebach o dużej populacji Bradyrhizobium.

W ujęciu syntezy z lat badań sposób zaopatrzenia roślin w azot istotnie wpłynął na wzrost plonu nasion w porównaniu z obiektem kontrolnym (tab. 7). Należy podkreślić również obfitsze plonowanie roślin po zastosowaniu dawki startowej azotu w porównaniu z obiektem z nitraginą, choć w doświadczeniu wykonanym w 2012 roku nie uzyskano istotnych różnic $\mathrm{w}$ plonie pomiędzy badanymi obiektami. Plon nasion soi był wyraźnie zróżnicowany w latach badań. W 2012 roku był największy i wyniósł 3,45 $\mathrm{t} \cdot \mathrm{ha}^{-1}$, a w $2011 \mathrm{roku}$ - najmniejszy i było to $2,76 \mathrm{t} \cdot \mathrm{ha}^{-1}$. Średnio w latach badań soja

Tabela 7. Plon nasion $\left(\mathrm{t} \cdot \mathrm{ha}^{-1}\right)$

Table 7. Seed yield $\left(\mathrm{t} \cdot \mathrm{ha}^{-1}\right)$

\begin{tabular}{|l|c|c|c|c|}
\hline \multirow{2}{*}{$\begin{array}{c}\text { Sposób zaopatrzenia } \\
\text { roślin w azot } \\
\begin{array}{c}\text { Method of plant } \\
\text { nitrogen supply }\end{array}\end{array}$} & 2011 & 2012 & 2013 & \multirow{2}{|c|}{$\begin{array}{c}\text { Satrednio } \\
\text { Mean }\end{array}$} \\
\cline { 2 - 5 } A & 2,57 & 3,20 & 2,82 & 2,86 \\
$\mathrm{~B}$ & 2,53 & 3,52 & 3,23 & 3,09 \\
$\mathrm{C}$ & 3,17 & 3,56 & 3,32 & 3,35 \\
$\mathrm{D}$ & 2,75 & 3,51 & 3,44 & 3,23 \\
\hline Średnio - Mean & 2,76 & 3,45 & 3,20 & 3,13 \\
\hline NIR $_{0,05}-\mathrm{LSD}_{0.05}$ & 0,185 & r.n. - n.s. & 0,349 & 0,218 \\
\hline
\end{tabular}

Objaśnienie A, B, C, D - jak w tabeli 2, r.n. - różnica nieistotna.

Explanation of A, B, C, D - as in Table 2, n.s. - difference not significant. 
Jarecki, W., Bobrecka-Jamro, D. (2016). Reakcja roślin soi na szczepienie nasion nitraginą oraz nawożenie startowe azotem. Nauka Przyr. Technol., 10, 1, \#12. DOI: 10.17306/J.NPT.2016.1.12

plonowała na poziomie 3,13 thha ${ }^{-1}$. Wielu autorów (Bujak i in., 2004; Candráková i in., 2008; Faligowska i Szukała, 2014) potwierdziło duży wpływ warunków pogodowych na plonowanie soi, jednak Lorenc-Kozik i Pisulewska (2003) podają, że odmiana 'Aldana' dość wiernie plonuje w latach. W doświadczeniach Lorenc-Kozik i Pisulewskiej (2003) nawożenie azotem wywarło korzystny wpływ na plonowanie badanych odmian soi. Stosowane przez te autorki dawki 30 i $60 \mathrm{~kg} \mathrm{~N}$ na 1 ha powodowały istotny przyrost plonu nasion soi. Crozat $\mathrm{i}$ in. (1994) podaje, że na produkcję $1 \mathrm{t}$ nasion soi wymagana jest dwukrotnie większa ilość azotu niż dla grochu. Bobrecka-Jamro i Pizło (1996) stwierdzają, że rośliny soi wydały największe plony, korzystając zarówno z azotu atmosferycznego, jak i mineralnego, z kolei Schmitt i in. (2001) oraz Freeborn $\mathrm{i}$ in. (2001) nie wykazali wpływu nawożenia azotem na plon nasion soi.

\section{Wnioski}

1. Warunki pogodowe wywarły znaczący wpływ na przebieg wegetacji i plonowanie soi. Badane sposoby zaopatrzenia roślin w azot wydłużały okres wegetacji roślin w porównaniu z obiektem kontrolnym, co ma ważny aspekt praktyczny.

2. Inokulacja nasion siewnych szczepionką bakteryjną - nitraginą wpłynęła na istotny wzrost liczby brodawek symbiotycznych na korzeniu pojedynczej rośliny w porównaniu z kontrolą (bez szczepionki). Nie wywarło to jednak istotnego wpływu na wskaźnik SPAD, wskaźnik MTA, indeks LAI czy cechy biometryczne roślin.

3. Dawka startowa azotu oraz nitragina stosowana łącznie $\mathrm{z}$ dawką startową azotu wpłynęły na istotny wzrost zieloności liści (SPAD), wartości indeksu powierzchni liści (LAI) oraz wysokości roślin w porównaniu z kontrolą. Istotną różnicę wysokości roślin uzyskano również pomiędzy obiektem nawożonym azotem a obiektem z nitraginą.

4. Większe wyleganie roślin i zarazem większą wartość MTN uzyskano na obiekcie nawożonym azotem niż na obiektach z nitraginą i kontrolnym. Liczbę nasion w strąku istotnie zwiększyła dawka startowa azotu, ale tylko w porównaniu z kontrolą. Szczepionka bakteryjna użyta łącznie $\mathrm{z}$ nawożeniem azotowym wpłynęła na istotnie wyższe osadzenie pierwszego strąka $\mathrm{w}$ porównaniu z roślinami kontrolnymi.

5. Wszystkie badane sposoby zaopatrzenia roślin w azot istotnie zwiększyły plon nasion w porównaniu z kontrolą. Ponadto obfitszy plon nasion uzyskano po zastosowaniu dawki startowej azotu niż po zastosowaniu szczepionki bakteryjnej - nitraginy.

\section{Literatura}

Albareda, M., Rodríguez-Navarro, D. N., Temprano, F. J. (2009). Use of Sinorhizobium (Ensifer) fredii for soybean inoculants in South Spain. Eur. J. Agron., 30, 3, 205-211.

Appunu, C., Sen, D., Singh, M., Dhar, B. (2008). Variation in symbiotic performance of Bradyrhizobium japonicum strains and soybean cultivars under field conditions. J. Centr. Eur. Agric., 9, 1, 169-174.

Bobrecka-Jamro, D., Pizło, H. (1996). Wpływ czynników agrotechnicznych na plonowanie soi w warunkach Polski południowo-wschodniej. Biul. Inst. Hod. Aklim. Rośl., 198, 31-44. 
Jarecki, W., Bobrecka-Jamro, D. (2016). Reakcja roślin soi na szczepienie nasion nitraginą oraz nawożenie startowe azotem. Nauka Przyr. Technol., 10, 1, \#12. DOI: 10.17306/J.NPT.2016.1.12

Boros, L. (2003). Ocena współzależności wybranych cech ilościowych determinujących plon nasion u grochu siewnego (Pisum sativum L.), fasoli karłowej (Ph. vulgaris L.) i soi (Glycine $\max$ L. Merrill). Biul. Inst. Hod. Aklim. Rośl., 226/227, 2, 481-486.

Bujak, K., Frant, M. (2009). Wpływ mieszanek herbicydów na plonowanie i zachwaszczenie pięciu odmian soi. Acta Agrophys., 13, 3, 601-613.

Bujak, K., Jędruszczak, M., Frant, M. (2004). Wpływ uproszczonej uprawy roli oraz dolistnego dokarmiania makro- i mikroelementami na plonowanie soi uprawianej w monokulturze. Ann. Univ. Mariae Curie-Skłodowska Sect. E, 59, 1, 139-147.

Bury, M., Nawracała, J. (2004). Wstępna ocena potencjału plonowania odmian soi (Glycine max (L.) Merrill) uprawianych w rejonie Szczecina. Rośl. Oleis. - Oilseed Crops, 25, 415-422.

Candráková, E., Macák, M., Szombathová, N., Hanáčková, E. (2008). The influence of fertilization on yield and yield component formation of soybean varieties. J. Cent. Eur. Agric., 9, 3, 511-518.

Cheng, Q. (2008). Perspectives in biological nitrogen fixation research. J. Integr. Plant Biol., 50, 7, 784-796.

Crozat, Y., Aveline, A., Coste, F., Gillet, J. P., Domenach, A. M. (1994). Yield performance and seed production pattern of field-grown pea and soybean in relation to $\mathrm{N}$ nutrition. Eur. $\mathrm{J}$. Agron., 3, 2, 135-144.

Dobek, T. K., Dobek, M. (2008). Efektywność produkcji soi w polskich warunkach. Inż. Roln., $12,102,4,233-240$.

Dobek, T. K., Dobek, M., Wojciechowska, J. (2009). Ekonomiczne i energetyczne aspekty produkcji soi w warunkach polskiego rolnictwa. Inż. Roln., 13, 115, 6, 37-43.

Faligowska, A., Szukała, J. (2014). Wpływ polimeru organicznego na komponenty plonowania i plon nasion soi uprawnej. Nauka Przyr. Technol., 8, 1, \#9.

Filoda, G., Mrówczyński, M. (red.). (2012). Metodyka integrowanej ochrony soi dla producentów. Poznań: IOR-PIB.

Florek, J., Czerwińska-Kayzer, D., Jerzak, M. A. (2012). Aktualny stan i wykorzystanie produkcji upraw roślin strączkowych. Fragm. Agron., 29, 4, 45-55.

Freeborn, J. R., Holshouser, D. L., Alley, M. M., Powell, N. L., Orcutt, D. M. (2001). Soybean yield response to reproductive stage soil-applied nitrogen and foliar-applied boron. Agron. J., 93, 6, 1200-1209.

Hungría, M., Franchini, J. C., Campo, R. J., Crispino, C. C., Moraes, J. Z., Sibaldelli, R. N. R., Mendes, I. C., Arihara, J. (2006). Nitrogen nutrition of soybean in Brazil: contributions of biological $\mathrm{N}_{2}$ fixation and $\mathrm{N}$ fertilizer to grain yield. Can. J. Plant Sci., 86, 4, 927-939.

Jerzak, M. J., Czerwińska-Kayzer, D., Florek, J., Śmiglak-Krajewska, M. (2012). Determinanty produkcji roślin strączkowych jako alternatywnego źródła białka - w ramach nowego obszaru polityki rolnej w Polsce. Rocz. Nauk Roln. Ser. G, 99, 1, 113-120.

Korsak-Adamowicz, M., Starczewski, J., Dopka, D. (2007). Oddziaływanie niektórych zabiegów agrotechnicznych na brodawkowanie soi. Fragm. Agron., 24, 3, 232-237.

Krivosudska, E., Filova, A. (2013). Evaluation of selected soybean genotypes (Glycine max L.) by physiological responses during water deficit. J. Cent. Eur. Agric., 14, 2, 691-706.

Księżak, J. (2006). Badania naukowe jako podstawa technologii uprawy roślin pastewnych. Pam. Puław., 142, 225-242.

Lorenc-Kozik, A. M., Pisulewska, E. (2003). Wpływ zróżnicowanego nawożenia azotem i mikroelementami na plonowanie wybranych odmian soi. Rośl. Oleis. - Oilseed Crops, 24, 131-142.

Martyniuk, S. (2012). Naukowe i praktyczne aspekty symbiozy roślin strączkowych z bakteriami brodawkowymi. Pol. J. Agron., 9, 17-22.

Podleśny, J. (2005). Rośliny strączkowe w Polsce - perspektywy uprawy i wykorzystanie nasion. Acta Agrophys., 6, 1, 213-224. 
Jarecki, W., Bobrecka-Jamro, D. (2016). Reakcja roślin soi na szczepienie nasion nitraginą oraz nawożenie startowe azotem. Nauka Przyr. Technol., 10, 1, \#12. DOI: 10.17306/J.NPT.2016.1.12

Reddy, K. N., Hoagland, R. E., Zablotowicz, R. M. (2000). Effect of glyphosate on growth, chlorophyll, and nodulation in glyphosate-resistant and susceptible soybean (Glycine max) varieties. J. New Seeds, 2, 3, 37-52.

Rodríguez-Navarro, D. N., Bellogín, R., Camacho, M., Daza, A., Medina, C., Ollero, F. J., Santamaría, C., Ruíz-Saínz, J. E., Vinardell, J. M., Temprano, F. J. (2003). Field assessment and genetic stability of Sinorhizobium fredii strain SMH12 for commercial soybean inoculants. Eur. J. Agron., 19, 2, 299-309.

Schmitt, M. A., Lamb, J. A., Randall, G. W., Orf, J. H., Rehm, G. W. (2001). In-season fertilizer nitrogen applications for soybean in Minnesota. Agron. J., 93, 5, 983-988.

Sujkowska, M. (2009). Przebieg procesu infekcji w układzie symbiotycznym rośliny motylkowate - Rhizobium. Wiad. Bot., 53, 1/2, 35-53.

Willems, A. (2006). The taxonomy of rhizobia: an overview. Plant Soil, 287, 3-14.

Yang, S. S., Bellogín, R. A., Buendía, A., Camacho, M., Chen, M., Cubo, T., Daza, A., Díaz, C. L., Espuny, M. R., Gutiérrez, R., Harteveld, M., Li, X. H., Lyra, M. C., Madinabeitia, N., Medina, C., Miao, L., Ollero, F. J., Olsthoorn, M. M., Rodríguez, D. N., Santamaría, C., Schlaman, H. R., Spaink, H. P., Temprano, F., Thomas-Oates, J. E., Van Brussel, A. A., Vinardell, J. M., Xie, F., Yang, J., Zhang, H. Y., Zhen, J., Zhou, J., Ruiz-Sainz, J. E. (2001). Effect of $\mathrm{pH}$ and soybean cultivars on the quantitative analyses of soybean rhizobia populations. J. Biotechnol., 91, 243-255.

\section{REACTION OF SOYBEAN PLANTS TO THE VACCINATION OF SEEDS WITH NITRAGINE AND INITIAL NITROGEN FERTILIZATION}

Summary. Strict field research was carried in the Research Station of Varieties Evaluation in Przecław in 2011-2013. The goal of the research was to observe the reaction of soybean plants to bacterial vaccination - nitragine and initial nitrogen fertilization. The variables were as follows: nitragine, initial dose of nitrogen $\left(25 \mathrm{~kg} \cdot \mathrm{ha}^{-1}\right)$, nitragine with initial nitrogen dose $\left(25 \mathrm{~kg} \cdot \mathrm{ha}^{-1}\right)$ and control object. The weather conditions considerably influenced plant vegetation and seed crop. Method of nitrogen supply, compared with control object, caused a prolongation of particular phases and differentiated biometric features of plants. Samples fertilized with initial nitrogen dose had increased plant lodging as compared with object with nitragine and with control object. Method of nitrogen supply considerably differentiated SPAD and LAI indicators but did not influence MTA indicator. Initial nitrogen fertilization caused an increase of seed number in a pod as compared with control sample and MTN increase as compared with object with nitragine and with control object. Vaccination of sowing seeds considerably increased the number of root nodules. On average roots of soybean plants produced 16 nodules. The yield mainly depended on the year the research was carried on in. Method of nitrogen supply considerably increased soybean yield as compared with the control sample. It was confirmed as well that initial nitrogen fertilization considerably influenced seed crop as compared with the used bacterial vaccination - nitragine.

Key words: soybean, bacterial vaccine - nitragine, initial nitrogen fertilization, seed yield, SPAD, LAI, MTA 
Jarecki, W., Bobrecka-Jamro, D. (2016). Reakcja roślin soi na szczepienie nasion nitraginą oraz nawożenie startowe azotem. Nauka Przyr. Technol., 10, 1, \#12. DOI: 10.17306/J.NPT.2016.1.12

Adres do korespondencji-Corresponding address:

Wacław Jarecki, Katedra Produkcji Roślinnej, Uniwersytet Rzeszowski, ul. Zelwerowicza 4, 35-601 Rzeszów, Poland, e-mail: waclaw.jarecki@wp.pl

Zaakceptowano do opublikowania-Accepted for publication:

4.02.2016

Do cytowania - For citation:

Jarecki, W., Bobrecka-Jamro, D. (2016). Reakcja roślin soi na szczepienie nasion nitragina oraz nawożenie startowe azotem. Nauka Przyr. Technol., 10, 1, \#12. DOI: 10.17306/J.NPT.2016.1.12 